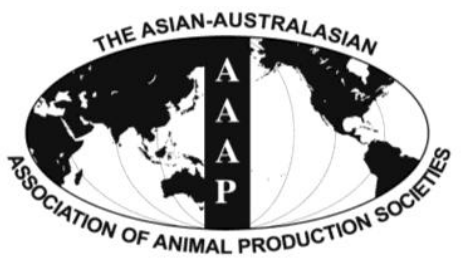

Asian-Aust. J. Anim. Sci.

Vol. 25, No. 11 : 1627-1633 November 2012

http://dx.doi.org/10.5713/ajas.2012.12302

www.ajas.info

pISSN 1011-2367 elSSN 1976-5517

\title{
Solid Waste from Swine Wastewater as a Fuel Source for Heat Production
}

\author{
Myung-Ho Park, Sanjay Kumar ${ }^{1}$ and ChangSix $\operatorname{Ra}^{1}{ }^{1 *}$ \\ Department of Mechanical Engineering, Kangwon National University, Chuncheon 200-701, Korea
}

\begin{abstract}
This study was to evaluate the feasibility of recycling the solids separated from swine wastewater treatment process as a fuel source for heat production and to provide a data set on the gas emissions and combustion properties. Also, in this study, the heavy metals in ash content were analyzed for its possible use as a fertilizer. Proximate analysis of the solid recovered from the swine wastewater after flocculation with organic polymer showed high calorific $(5,330.50 \mathrm{kcal} / \mathrm{kg})$ and low moisture $(15.38 \%)$ content, indicating that the solid separated from swine wastewater can be used as an alternative fuel source. CO and NOx emissions were found to increase with increasing temperature. Combustion efficiency of the solids was found to be stable (95 to $98 \%$ ) with varied temperatures. Thermogravimetry (TG) and differential thermal analysis (DTA) showed five thermal effects (four exothermic and one endothermic), and these effects were distinguished in three stages, water evaporation, heterogeneous combustion of hydrocarbons and decomposition reaction. Based on the calorific value and combustion stability results, solid separated from swine manure can be used as an alternative source of fuel, however further research is still warranted regarding regulation of $\mathrm{CO}$ and NOx emissions. Furthermore, the heavy metal content in ash was below the legal limits required for its usage as fertilizer. (Key Words: DTA, Energy, Flocculation, Swine Wastewater, Thermogravimetry)
\end{abstract}

\section{INTRODUCTION}

The growing demand for meat and meat production has been on a steady increase in both developed and developing countries (Yetilmezsoy et al., 2009). Therefore, the concentration of animal production systems and consequently animal wastewater production has proportionately increased. In many cases, the production of manure from one or more animal species is in excess of what can be safely applied to farmland in accordance with nutrient management plans, and stock piled waste poses economic and environmental liabilities. This biowaste contributes to eutrophication of water bodies, spread of pathogens, production of phytotoxic substances and air pollution with the release of $\mathrm{CH}_{4}$ (a green house gas), $\mathrm{NH}_{3}$, $\mathrm{H}_{2} \mathrm{~S}$, amides, volatile organic acids, mercaptans, esters, and other compounds (Sweeten et al., 2003; Zhou et al., 2012). Therefore, effective treatment of animal manure must be implemented before its discharge into the environment.

\footnotetext{
* Corresponding Author: ChangSix Ra. Tel: +82-33-250-8618, Fax: +82-33-251-7719, E-mail: changsix@ kangwon.ac.kr

1 Department of Animal Life System, Kangwon National University, Chuncheon 200-701, Korea.

Submitted May 31, 2012; Accepted Aug. 13, 2012; Revised Sept. 6, 2012
}

Approaches currently in use for proper manure management are biological nutrient removal, anaerobic digestion (generate energy), and composting (solid fertilizer) (Gonzalez-Fernandez et al., 2008). The solidliquid separation is critical for the accomplishment of the above mentioned techniques. In order to improve the settling characteristics of solids in manure, chemical methods are commonly being used and many inorganic chemicals (ferric chloride and aluminium sulphate) (Zhang and Lei, 1998) and organic polymers (polyacrylamides and chitosan) have been used as coagulants and flocculants for separation augmentation. Among the organic polymers, polyacrylamides have been widely studied for swine wastes (Vanotti and Hunt, 1999; Ebeling et al., 2005). These polymers are proven to be effective for flocculating suspended solids (SS) and separating organic nutrients from swine wastewater with low dosage demand. After separation of solids, the wastewater is purified by physical and biological processes before being discharged and the leftover solid is passed through a composting process. Their utilization as a solid fuel source would be a good method of management/or treatment of the separated solids especiaaly in view of rising energy prices. Furthermore, if the amount of heavy metals in the resulting ash after combustion were 
less than the prevailing regulations, it could be used as a fertilizer.

The development of thermal treatment of biomass waste was driven by restrictions of gas emission standards and requirements of residue qualities by legislative regulations due to concerns over public health and the environment (Freeman, 1997; Frey et al., 2003). Recent research efforts have shown that biomass (manure) fuels are considered to be environmentally friendly for several reasons. Biomass wastes bring additional greenhouse gas mitigation by avoiding $\mathrm{CH}_{4}$ release from land filling (Hein and Bemtgen, 1998; Spliethoff and Hein, 1998). There is no net increase in $\mathrm{CO}_{2}$ as a result of burning a biomass fuel because biomass consumes the same amount of $\mathrm{CO}_{2}$ from the atmosphere during growth as it is released during combustion (Easterly and Brunham, 1996).

In this study to determine the feasibility of recycling of the solids separated from the swine wastewater treatment process their energy content, efficiency of complete combustion and gas emissions properties during combustion were studied. Also the heavy metal content before and after combustion was analyzed to determine whether the generated ash can be used as fertilizer.

\section{MATERIALS AND METHODS}

\section{Separation of solids from swine wastewater}

Slurry form swine (feeder to finish) wastewater was collected from the university farm and kept at $4{ }^{\circ} \mathrm{C}$ until used. For separation of the solids from wastewater, the slurry was flocculated with 100 times diluted polymer (commercial organic polymer, Nalco 855) at a rate of 50 $\mathrm{mg} / \mathrm{L}$, and then the mixture was stirred for $30 \mathrm{~min}$ and kept for $1 \mathrm{~h}$ for settlement. The separated solids from the swine wastewater were dried in an open plastic vessel for $3 \mathrm{~d}$ under natural conditions (i.e., in an experimental shed) for the evaluation of the solid waste to be recycled as a solid fuel.

\section{Analysis}

The wastewater collected after solid separation was analyzed for total solid (TS), suspended solids (SS), ammonia-nitrogen $\left(\mathrm{NH}_{4}-\mathrm{N}\right)$, orthophosphate $(\mathrm{OP})$, total Kjeldahl nitrogen (TKN), total phosphate (TP), and total soluble organic carbons (TOCs). $\mathrm{NH}_{4}-\mathrm{N}, \mathrm{OP}, \mathrm{TKN}$, and TP were analyzed with an auto water analyzer (Quick Chem 8500, LACHAT), and TOCs wereanalyzed using a Total Organic Carbon Analyzer (Shimadzu, TOC-5000A). The separated solid after natural drying was measured for moisture, TS, volatile solid (VS), ash and energy level. For estimation of moisture content, the solids were dried in electric oven at approximately $105^{\circ} \mathrm{C}$ for $24 \mathrm{~h}$. For VS and ash, the weight of solids was measured before and after ignition at $550^{\circ} \mathrm{C}$ for $4 \mathrm{~h}$ and the VS being the difference
Table 1. Operational condition during combustion

\begin{tabular}{lc}
\hline Parameters & Conditions \\
\hline Average combustion temperature & $100-300^{\circ} \mathrm{C}$ \\
Fuel moisture content & $15.38 \%$ \\
Air ratio & $3.89-4.47$ \\
\hline
\end{tabular}

between the dried solids and the ash. All the analyses were carried out according to APHA (2005) in triplicate. The calorific value of the solid waste was measured by burning the weighed $(0.5 \mathrm{~g})$ sample in an oxygen bomb calorimeter according to ASTM E-711.

\section{Flue gas analysis}

A combustion experiment was done with a small boiler furnace consisting of fine grid body, fuel supply, combusting chamber and the ash pan. The furnace had an area of 66 to $132 \mathrm{~m}^{2}$. Boiler dimensions $(\mathrm{W} \times \mathrm{L} \times \mathrm{H})$ were $650 \times 1,230 \times 1,600(\mathrm{~mm})$ with a capacity of $110 \mathrm{~L}$ for liquid and $210 \mathrm{~kg}$ for solid. Operating conditions during combustion are given in Table 1 . The analysis of the flue gas composition was carried out immediately using "Combustion Gas Analyzer" (ECOM Ltd America, ECOM - AC 2.), and a multi-component gas analyzer was used for online measurements of $\mathrm{CO}, \mathrm{NO}, \mathrm{SO}_{2}$ and $\mathrm{O}_{2}$. Table 2 shows the ranges for the different gas components. The microprocessor calculated $\mathrm{CO}_{2}$ and combustion efficiency.

\section{Thermogravimetry and ash analysis}

The separated solids from swine wastewater were subjected to TG and DT analysis in nitrogen and air atmosphere using STA 409 PC Luxx ${ }^{\circledR}$ Simultaneous TGADTA analyzer, where the mass loss, TG, and temperature changes were recorded simultaneously. Thermogravimetric curves were obtained at a heating rate of $10^{\circ} \mathrm{C} / \mathrm{min}$. Purified nitrogen and air at a flow rate of around $50 \mathrm{ml} / \mathrm{min}$ was used as the purge gas to provide an inert/oxidative atmosphere for pyrolysis and combustion, respectively. Mineral analysis of the solid and ash were examined through the optical emission spectroscopy.

\section{RESULTS AND DISCUSSION}

Content of solids in wastewater is an important

Table 2. Measuring ranges for different gas components

\begin{tabular}{llc}
\hline & Range & Method \\
\hline $\mathrm{O}_{2}$ & $0-21 \%$ vol. & Electrochemical \\
$\mathrm{CO}$ & $0-4,000 \mathrm{ppm}$ & Electrochemical \\
$\mathrm{SO}_{2}$ & $0-5,000 \mathrm{ppm}$ & Electrochemical \\
$\mathrm{NO}$ & $0-500 \mathrm{ppm}$ & Electrochemical \\
$\mathrm{CO}_{2}$ & $0-\mathrm{CO}_{2} \mathrm{Max}$ & Calculated \\
Efficiency & $0-100 \%$ & Calculated \\
Lambda (Excess air $\lambda)$ & $0-50 \%$ & Calculated \\
\hline
\end{tabular}


parameter for the control of flocculation treatments (Vanotti et al., 2002). In order to remove solids from swine wastewater, which are responsible for the oxygen requirement in further treatment processes, the wastewater was flocculated with polymer. As shown in Table 3, the removal efficiencies of TS and SS were 28.19 and $73.57 \%$, respectively. Vanotii and Hunt (1999) obtained removal of $96 \%$ for SS, using $200 \mathrm{ppm}$ of polyacrylamide (PAM) on a raw wastewater of $6.7 \mathrm{~g} / \mathrm{L}$ TS and Gonzalez-Fernandez (2008) reported $79 \%$ of SS removal with 120 ppm of PAM dosage. In this study, a lower removal efficiency was achieved probably due to the lower concentration of polymer used (<50 ppm). In general, removal efficiency of TS and SS depends on their initial concentration in raw wastewater as well as on type and concentration of polymer used.

Ammonia-nitrogen was found to increase in the effluent, probably due to the chemical composition of the polymer, whereas OP, TKN, TP and TOCs were decreased in the effluent, showing 45.53, 12.10, 74.23 and $59.41 \%$ removal, respectively. With respect to phosphorus, GonzalezFernandez (2008) and Timby et al. (2004) concluded that flocculation with PAM did not affect soluble phosphorus in dairy and swine wastewater. None of the authors working on swine wastewater have reported soluble phosphorus removal by flocculation treatment, except for Vanotti et al. (2003) who found a 17\% removal of soluble P with flocculation and a separation treatment. This removal was unexpected since flocculation is supposed to affect the non soluble phosphorus, but some researchers working with a different kind of wastewater have observed this phenomenon when using polyacrylamides as flocculation aids (Ebeling et al., 2005) and the removal of soluble P was attributed to the removal of TS and SS. This fact may explain the results of soluble $\mathrm{P}$ removal in our study. A similar trend was also observed in case of TOCs.

\section{Proximate analysis}

The main physio-chemical parameters which determine the potential recovery of energy from solid wastes are density, moisture content and calorific value (Houshfar et al., 2010). Wastes of high density reflect a high proportion of biodegradable organic matter and moisture. High moisture $(>45 \%)$ makes the waste rather unsuitable for thermo-chemical conversion for energy recovery as heat must first be supplied to remove moisture. The results obtained in the present study are shown in Table 4 . The
Table 3. Characteristics of the swine wastewater before and after solid separation

\begin{tabular}{lccc}
\hline Parameters & Influent & Effluent & $\begin{array}{c}\text { Removal } \\
(\%)\end{array}$ \\
\hline TS $(\mathrm{g} / \mathrm{L})$ & $8.44 \pm 0.45$ & $6.06 \pm 0.11$ & 28.19 \\
$\mathrm{SS}(\mathrm{g} / \mathrm{L})$ & $2.8 \pm 0.45$ & $0.74 \pm 0.06$ & 73.57 \\
$\mathrm{NH}_{4}-\mathrm{N}(\mathrm{mg} / \mathrm{L})$ & $432.68 \pm 10.52$ & $556.61 \pm 5.77$ & -22.62 \\
$\mathrm{OP}(\mathrm{mg} / \mathrm{L})$ & $9.97 \pm 0.35$ & $5.43 \pm 0.1$ & 45.53 \\
$\mathrm{TKN}(\mathrm{mg} / \mathrm{L})$ & $4,119.76 \pm 21.30$ & $3,621.23 \pm 97.26$ & 12.10 \\
$\mathrm{TP}(\mathrm{mg} / \mathrm{L})$ & $56.48 \pm 7.30$ & $14.55 \pm 4.06$ & 74.23 \\
TOCs $(\mathrm{mg} / \mathrm{L})$ & $3,993.5 \pm 112.43$ & $1,620.9 \pm 106.77$ & 59.41 \\
\hline
\end{tabular}

\pm : Standard error where $\mathrm{n}=3$.

calorific value of the solid is much higher $(5,330.40$ $\mathrm{kcal} / \mathrm{kg}$ ) compared to those of horse manure mixed with wood shavings $(4,626.44 \mathrm{kcal} / \mathrm{kg})$ having moisture content of $57 \%$ (Lundgren and Pettersson, 2009), poultry litter having moisture content of $15.02 \%$ and calorific content of $1,440.24 \mathrm{kcal} / \mathrm{kg}$ (Zhu et al., 2005) and feedlot manure having 4,991.87 $\mathrm{kcal} / \mathrm{kg}$ calorific value (Sweeten et al., 2003). Therefore, it appears that the sludge or solids produced from the swine wastewater treatment process $y$ using an organic polymer could be a useful source for energy generation. The TS, organic and inorganic content were found to be $84.61,67.10$ and $32.89 \%$, respectively.

\section{Emission of gases}

Both $\mathrm{CO}$ and NOx emissions depend upon matter characteristics, operating condition temperature and excess air etc. $\mathrm{CO}$ and NOx fluctuate more with higher sludge solid content (TS) (Dangtran et al., 2000). Figure 1b shows that with an increase in temperature from 100 to $240^{\circ} \mathrm{C}$, there was an increase in $\mathrm{CO}$ (600 to $880 \mathrm{ppm}$ ) and NOx (375 to $420 \mathrm{ppm}$ ) emissions. In the case of $\mathrm{CO}$, an increase in emission was observed in steady intervals at 140 to 160 and 180 to $200^{\circ} \mathrm{C}$, whereas in the case of NOx increased emission was observed till $180^{\circ} \mathrm{C}$ and thereafter emission was stable. Gases emitted from the combustion chamber are mainly $\mathrm{NO}_{2}$ and $\mathrm{NO}$, which are collectively defined as $\mathrm{NOx}$. NOx emission can be categorized as thermal NOx, prompt NOx and fuel NOx. During gas fuel or denitrified fuel combustion, thermal NOx and prompt NOx are produced. If nitrogen content is $>3 \%$ as in case of heavy oil or charcoal, then fuel NOx is main cause of NOx production. In this experiment, NO produced from the solids was less than 400 ppm which is comparatively lower than the standard environmental value (500 ppm).

Table 4. Proximate analysis of the solid waste

\begin{tabular}{|c|c|c|c|c|}
\hline Proximate analysis & Solid (this study) & Horse manure $^{a}$ & Poultry litter $^{\mathrm{a}}$ & Feedlot manure $^{\mathrm{a}}$ \\
\hline Moisture content (\%) & $15.38 \pm 0.12$ & 57.00 & 15.02 & 38.60 \\
\hline Calorific value (kcal/kg) & $5,330.40 \pm 34.20$ & $4,626.44$ & $1,440.24 *$ & $4,991.87 *$ \\
\hline
\end{tabular}

\footnotetext{
* Lower heating value. ${ }^{\mathrm{a}}$ Data from Lundgren and Pettersson, 2009 (converted to $\mathrm{kcal} / \mathrm{kg}$ ). \pm : Standard error where $\mathrm{n}=3$.
} 

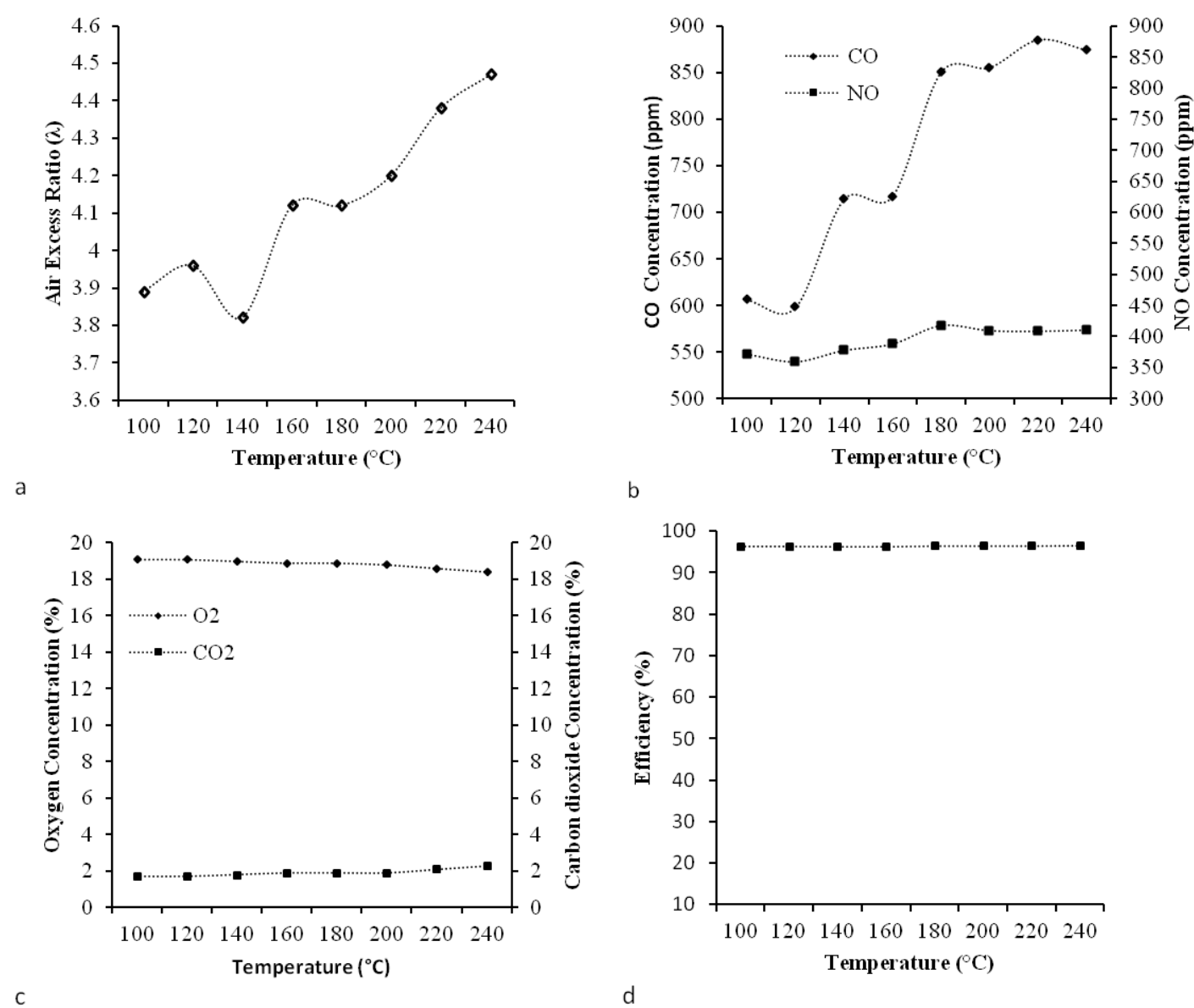

b

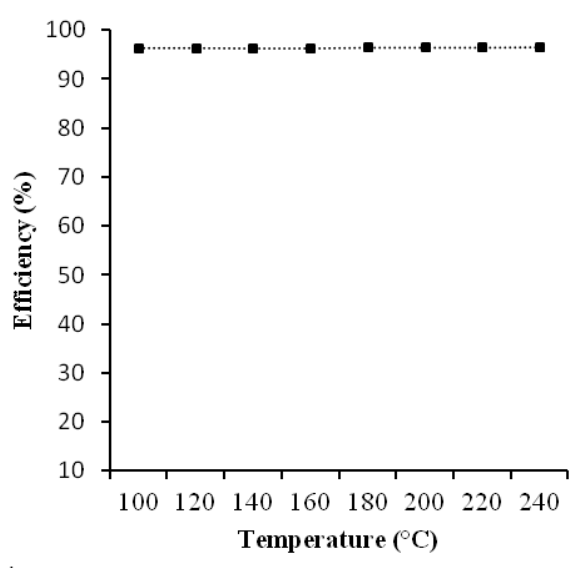

Figure 1. Fuel characteristics of solid wastes as function of temperature. (a) Air excess ratio (\%); (b) CO and NOx concentration; (c) $\mathrm{CO}_{2}$ and $\mathrm{O}_{2}$ concentration; (d) Combustion efficiency.

The slight increase in NOx with increase in temperature could be due to the release of fuel- $\mathrm{N}$ from $\mathrm{NH}_{3}$ groups and thus enhanced formation of NOx coming from a small percentage of nitrogen bound in the sludge (Zhu et al., 2005). Similar results were also obtained by Zhu and Lee (2005) while assessing temperature effect on NOx emission of sawdust, poultry litter and manure co-combusted with natural gas.

From Figure 1a, it can be noticed that air excess ratio was increasing with the increase in temperature. With increase in the combustion temperature, $\mathrm{CO}$ concentration value was observed to be high (Figure 1b). CO concentration in flue gas heavily relies on air fuel ratio (equivalence ratio; $\varnothing$ ). With high $\mathrm{O}_{2}$ content there is complete oxidation of $\mathrm{CO}$ to $\mathrm{CO}_{2}$, but with a lack of $\mathrm{O}_{2}$ a large amount of $\mathrm{CO}$ is produced. In other words, if $\varnothing>1$, there is significant increase in $\mathrm{CO}$ emission conversely if $\emptyset<1$ only small concentration of $\mathrm{CO}$ is formed. Hence, for low $\mathrm{CO}$ emission a high air-fuel ratio is required.

The $\mathrm{CO}_{2}$ concentration was nearly $2 \%$, and no noticeable change in concentration was observed with an increase or decrease of temperature as depicted (Figure 1c). The combustion efficiency was between 95 to $98 \%$, suggesting the stable combustion in progress (Figure 1d).

\section{Thermogravimetry analysis}

TG analysis of the separated solid from swine wastewater at $10^{\circ} \mathrm{C} / \mathrm{min}$ is presented in Figure 2 . Concerning the TG data five thermal effects were clearly identified. The correlation between TG data and DTA curves contributed to the interpretation of these thermal effects. Four exothermal (in the temperature ranges 373.2, $459.1,611.9$ and $\left.960.2^{\circ} \mathrm{C}\right)$ and one endothermal $\left(107.5^{\circ} \mathrm{C}\right)$ peaks were determined during TG-DTA anlaysis. The peak at $107.5^{\circ} \mathrm{C}$ was caused by the volatilization of water in the solids (Iordanidis et al., 2001; Xiu et al., 2012). DTA curves indicate that it was an endothermic stage under inert conditions. Mass change of $1.20 \%$ was observed at this stage. Following this a huge mass change of $40.87 \%$ and $37.50 \%$ was observed between 200 to $400^{\circ} \mathrm{C}$ and 400 to $600^{\circ} \mathrm{C}$, respectively. Consequently, $80 \%$ mass change was noticed in the temperature range of 200 to $680^{\circ} \mathrm{C}$. The DTA curve displayed two exothermic peaks in this region, which is probably due to the decomposition reaction of the heavy components (hydrocarbons) in the solids (Xiu et al., 2012). After this intensive mass change, low mass changes of 1.80 


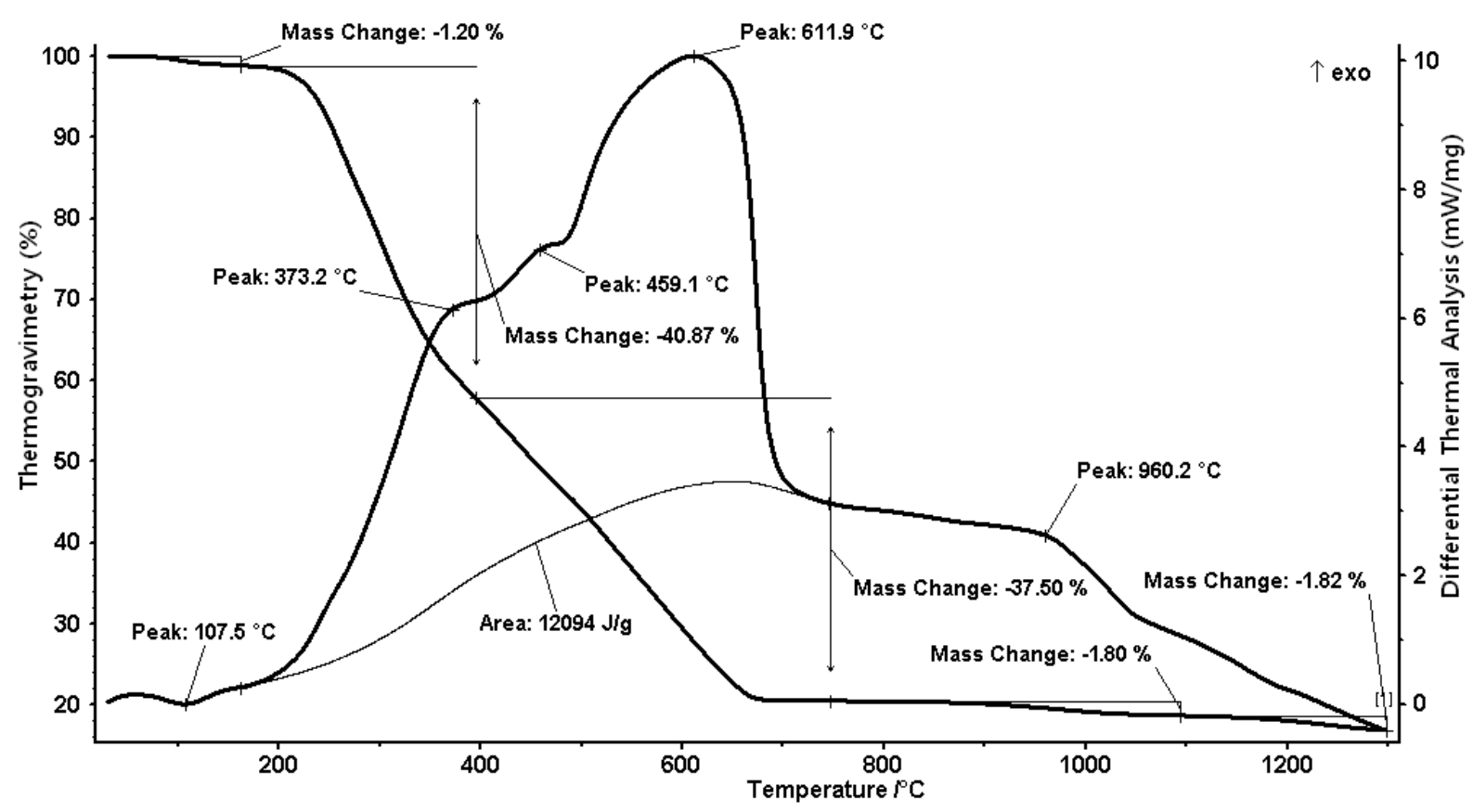

Figure 2. TG/DTA thermograms for swine manure at heating rate of $10^{\circ} \mathrm{C} / \mathrm{min}$ under $\mathrm{N}_{2}$ atmosphere.

and 1.87 were observed in the temperature range of 900 to 1,080 and 1,180 to $1,290^{\circ} \mathrm{C}$, respectively. A total of $83.19 \%$ mass change was observed overall. On the basis of data obtained, the combustion of the separated solid from swine wastewater can be divided into three phases: In the first phase, water and light compounds volatilized and were oxidized, which occurred before $200^{\circ} \mathrm{C}$; in the second phase, the heterogeneous combustion occurred between the heavy hydrocarbons and oxygen; this lead to the main weight loss in the second region. DTA curve analysis around $611.9^{\circ} \mathrm{C}$ showed an exothermic peak having a calorific value of $2,889.29 \mathrm{cal} / \mathrm{kg}$. In the third stage, the char that was formed during the previous process of evaporating and cracking was observed by two peaks in the temperature of more than $900^{\circ} \mathrm{C}$.

\section{Mineral analysis (mass \%) of the bottom ash}

Optical emission spectrometric analysis was done to analyze inorganic components of the solid separated from swine wastewater and of bottom ash after combustion (Table 5). The analysis of the major inorganic components of the bottom ash compared with the solid showed decreased concentration of $\mathrm{SO}_{3}, \mathrm{Cl}$ and $\mathrm{K}_{2} \mathrm{O}$ in bottom ash, whereas substantial increase in $\mathrm{MgO}, \mathrm{SiO}_{2}$, and $\mathrm{P}_{2} \mathrm{O}_{5}$ was noticed after combustion.

Coal ash showed lower amount of $\mathrm{Na}_{2} \mathrm{O}, \mathrm{K}_{2} \mathrm{O}$ and higher content of $\mathrm{Al}_{2} \mathrm{O}_{3}, \mathrm{SiO}_{2}$ and $\mathrm{Fe}_{2} \mathrm{O}_{3}$ compared to horse manure and the bottom ash. Ca content of the bottom ash was higher than that of the horse fuel mixture and comparable to coal ash, thus can have higher capacity of self hardening due to formation of limestone (in humid conditions) on reaction with carbon dioxide. Nitrogen content is completely absent from the ash. The phosphorus content in the ash is high, and thus can replenish the lost phosphorus content of the soil. Since, heavy metals are an important issue with regard to assessing the quality of ash as possible fertilizer, the heavy metal content in the ash as well solid fuel was analyzed (Table 6). As and Se decreased in the bottom ash while $\mathrm{Cd}, \mathrm{Cr}, \mathrm{Cu}, \mathrm{Co}, \mathrm{Mo}, \mathrm{Ni}, \mathrm{Pb}$ and $\mathrm{Zn}$ increased. On comparing the legal limits stated by DuMV (2003), the ash contained much lower heavy metal content than the limit values. Sweeten et al. (2003) and Lundergen

Table 5. Comparison of major inorganic components in solid waste before and after burning

\begin{tabular}{lcccc}
\hline & \multicolumn{4}{c}{ Mass $(\%)$} \\
\cline { 2 - 5 } Components & $\begin{array}{c}\text { Solid } \\
\text { waste }\end{array}$ & $\begin{array}{c}\text { Bottom } \\
\text { ash }\end{array}$ & $\begin{array}{c}\text { Horse } \\
\text { manure* }\end{array}$ & $\begin{array}{c}\text { Coal } \\
\text { ash** }\end{array}$ \\
\hline $\mathrm{Na}_{2} \mathrm{O}$ & 2.10 & 2.08 & 2.59 & 0.94 \\
$\mathrm{MgO}$ & 5.39 & 7.42 & 8.85 & 5.53 \\
$\mathrm{Al}_{2} \mathrm{O}_{3}$ & 0.95 & 1.38 & 7.75 & 19.08 \\
$\mathrm{SiO}_{2}$ & 4.31 & 6.24 & 42.6 & 28.7 \\
$\mathrm{P}_{2} \mathrm{O}_{5}$ & 15.80 & 24.0 & 4.27 & - \\
$\mathrm{SO}_{3}$ & 13.0 & 8.95 & - & 9.86 \\
$\mathrm{Cl}$ & 6.73 & 3.29 & - & - \\
$\mathrm{K}_{2} \mathrm{O}$ & 19.1 & 12.5 & 11.5 & 0.5 \\
$\mathrm{CaO}$ & 25.7 & 25.7 & 15.4 & 27.9 \\
$\mathrm{TiO}_{2}$ & 0.13 & 0.14 & 0.44 & 1.34 \\
$\mathrm{Fe}_{2} \mathrm{O}_{3}$ & 3.40 & 3.92 & 4.24 & 5.58 \\
\hline
\end{tabular}

* Data from Lundergen and Petterson (2009).

** Data from Sweeten et al. (2003). 
Table 6. Heavy metal contents in the bottom ash and in the solid waste $(\mathrm{mg} / \mathrm{kg})$ and its comparison with legal limit stated by Dungemittelverordnung

\begin{tabular}{lccc}
\hline $\begin{array}{c}\text { Element } \\
(\mathrm{mg} / \mathrm{kg})\end{array}$ & Bottom ash & Solid waste & $\begin{array}{c}\text { Limit values } \\
\text { according to } \\
\text { DuMV, 2003 }\end{array}$ \\
\hline $\mathrm{As}$ & 0.011 & 0.017 & - \\
$\mathrm{Cd}$ & $\mathrm{ND} *$ & $\mathrm{ND}$ & 1.5 \\
$\mathrm{Cr}$ & 0.111 & 0.015 & 2.0 \\
$\mathrm{Cu}$ & 9.868 & 2.036 & 70 \\
$\mathrm{Co}$ & 0.048 & 0.003 & - \\
$\mathrm{Hg}$ & $\mathrm{ND}$ & $\mathrm{ND}$ & - \\
$\mathrm{Mo}$ & 0.125 & 0.016 & - \\
$\mathrm{Ni}$ & 0.196 & 0.032 & 80 \\
$\mathrm{~Pb}$ & 0.067 & 0.026 & 150 \\
$\mathrm{Se}$ & $\mathrm{ND}$ & $\mathrm{ND}$ & - \\
$\mathrm{Zn}$ & 31.279 & 5.617 & 1,000 \\
\hline$*$ Non-detectable. & & &
\end{tabular}

and Petterson (2009), reported that heavy metal contents in ash must be lower than the legal limits for its use as fertilizer or before being recycled to forests.

\section{IMPLICATIONS}

From the experimental studies on swine wastewater carried out in the present work the following conclusions can be drawn: i) The energy content of the solid or sludge separated from swine wastewater using organic polymer was $5,330.40 \mathrm{kcal} / \mathrm{kg}$. The $\mathrm{CO}$ and $\mathrm{NOx}$ emission was found to increase with increasing temperature. The $\mathrm{O}_{2}$ content and excess air ratio was higher and was responsible for high CO and NOx emission, ii) The TG-DTA analysis suggested that the combustion of the sludge separated from swine wastewater treatment plants could be processed in three stages. First stage and third stage showed lower mass loss due to water evaporation and decomposition, whereas in the second stage a high mass loss of $80 \%$ was observed, iii) Ash contained high fertilizer sources such as $\mathrm{MgO}, \mathrm{P}_{2} \mathrm{O}_{5}$, $\mathrm{CaO}$ and $\mathrm{K}_{2} \mathrm{O}$, while heavy metal content was very low compared to legal limits and iv) The sludge produced by using organic polymer in swine wastewater treatment process can be used as fuel with high combustion efficiency, however, $\mathrm{CO}$ and NOx emission should be regulated.

\section{ACKNOWLEDGEMENT}

This research was performed with the support of Rural Development Administration (RDA), Korea.

\section{REFERENCES}

APHA. 2005. Standard methods for the examination of water and wastewater. 21st edn. American Public Health Association,
Washington, DC, USA.

Dangtran, K., J. F. Mullen and D. T. Mayrose. 2000. A comparison of fluid bed and multiple hearth sludge incineration, Presented at the 14th Annual Residual and Sludge Incinerator Emissions, WERF Project 91-ISP-1.

Decolorization and COD reduction of UASB pretreated poultry manure wastewater by electrocoagulation process: A posttreatment study. J. Hazard. Mater. 162:120-132.

German Fertilizer Regulations, Dungemittelverordnung 2003. Verordnung uber das Inverkehrbringen von Dungemitteln, Bodenhilffftoffen, Kultursubstraten und Pflanzenhilfsmitteln.

Easterly, J. L. and M. Brunham. 1996. Overview of biomass and waste fuel resources for power production. Biomass Bioenergy 10:79-92.

Ebeling, J. M., K. L. Rishel and P. L. Sibrell. 2005. Screening and evaluation of polymers as flocculation aids for the treatment of aqualculture effluents. Aquac. Eng. 33:235-249.

Ferrer, M., F. Orus and E. Monge. 2000. Determinacion de formas nitrogenadas en estiercol fluido de porcino (EFP) pro distinos metodos analiticos. Anaporc. 205:86-101.

Freeman, H. M. 1997. Standard Handbook of Hazardous Waste Treatment and Disposal. McGraw Hill, NY, ISBN 0070220442.

Frey, H. H., B. Peters and H. Hunsinger. 2003. Characterization of municipal solid waste combustion in a grate furnace. Waste Manag. 23:689-701.

Gonzalez-Fernandez, C., P. P. Nieto-Diez, C. Leon-Cofreces and P. A. Garcia-Encina. 2008. Solids and nutrients removal from liquid fraction of swine manure slurry through screening and flocculation treatment and influence of these processes on anaerobic biodegradability. Bioresour. Technol. 99:6233-6239.

Hein, K. P. G. and J. M. Bemtgen. 1998. EU clean coal technology, co combustion of coal and biomass. Fuel Process Technol. 54: 159-169.

Houshfar, E., T. Lovas and O. Q. Skreiberg. 2010. Detailed chemical kinetics modeling of NOx reduction in combined staged fuel and staged air combustion of biomass. 18th European Biomass Conference and Exhibition, Lyon, France. pp. 1128-1132.

Iordanidis, A., A. Georgakopoulos, K. Markova, A. Filippidis and A. Kassoli-Fournarraki. 2001. Application of TG-DTA to the study of Amynteon lignites, northern Greece. Thermo Acta. 371:137-141.

Lundgren, J. and E. Pettersson 2009. Combustion of horse manure for heat production. Bioresour. Technol. 100:3121-3126.

Spliethoff, H. and K. P. G. Hein. 1998. Effect of co-combustion of biomass on emissions in pulverized fuel furnaces. Fuel Process Technol. 54:189-205.

Sweeten, J. M., K. Annamalai, B. Thien and L. A. McDonald. 2003. Co-firing of coal and cattle feedlot biomass (FB) fuels. Part I. Feedlot biomass (cattle manure) fuel quality and characteristics. Fuel 82:1167-1182.

Timby, G. G., T. C., Daniel, R. W. McNew and P. A. Moore. 2004. Polymer type and aluminium chloride effect screened solids and phosphorus removal from liquid dairy manure. Appl. Eng. Agric. 20:57-64.

Vanotti, M. B. and P. G. Hunt. 1999. Solids and nutrient removal from flushed swine manure using polyacrylamides. Trans. Am. Soc. Agric. Eng. 42:1833-1840.

Vanotti, M. B., P. G. Hunt, A. Szogi, F. Humenik, P. Millner and A. 
Ellison. 2003. Solids separation, nitrification-denitrification, soluble phosphorus removal, solids processing system. In: Proceedings of the North Carolina Animal Waste Management Workshop, pp. 30-35.

Vanotti, M. B., D. M. C. Rashash and P. G. Hunt. 2002. Solidliquid separation of flushed swine manure with PAM: effect of wastewater strength. Trans. Am. Soc. Agric. Eng. 45:19591969.

Xiu, S., H. K. Rojanala, A. Shahbazi, E. H. Finni and L. Wang. 2012. Pyrolysis and combustion characteristics of Bio-oil from swine manure. J. Therm. Anal. Calorim. 107:823-829.
Yetilmezsoy, K., F. Ilhan, Z. Sapci-Zengin, S. Sakar and M. T. Gonullu. 2009. Decolorization and COD reduction of UASB pretreated poultry manure wastewater by electrocoagulation process: A post-treatment study. J. Hazard. Mat. 162:120-132.

Zhang, R. H. and F. Lei. 1998. Chemical treatment of animal manure for solid-liquid separation. Trans. Am. Soc. Agric. Eng. 41:1103-1108.

Zhou, S., X. Zhang and X. Chen. 2012. Pozzolanic activity of feedlot biomass (cattle manure) ash. Constr. Build. Mater. 28: 493-498.

Zhu, S. and S. W. Lee. 2005. Co-combustion performance of poultry waste and natural gas in the advanced Swirling Fluidized Bed Combustor (SFBC). Waste Manag. 25:511-518. 